\title{
Determinants Influencing Entrepreneurial Intention in Hanoi, Vietnam
}

\author{
Dinh Toan Nguyen, Manh Dung Tran \\ National Economics University, Vietnam

\begin{abstract}
Ngoc Chi Le, Hoang An Nguyen, My Hang Phuong Le, Khanh Vi Mac, Duc Hai Dinh
\end{abstract} \\ School of Advanced Education Programs, National Economics University, Vietnam
}

\begin{abstract}
This research employed survey data from 204 students between two groups of economics and technical majors in Hanoi city for assessing the impact levels of determinants on entrepreneurial intention. The results show that a number of determinants including Need for achievement, Self-efficacy, and Instrumental readiness have positive impacts on student's entrepreneurial intention. Besides, this study is also to create a basis for comparative students among different economics and technical majors, work exoperience, and gender. These findings are the basis to recommend policies and solutions to promote entrepreneurship movement in Vietnam.
\end{abstract}

Keywords: Entrepreneurial intention, need for achievement, self-efficacy, instrumental readiness.

DOI: $10.7176 / \mathrm{EJBM} / 12-15-10$

Publication date:May $31^{\text {st }} 2020$

\section{Introduction}

Vietnam in general and Hanoi capital in particular have witnessed the emergence of a new "flow" of remarkable entrepreneurship. Despite the difficulties, the start-up and entrepreneur market in Vietnam is still on the top 3 of thriving start-up and entrepreneur markets in Southeast Asia, along with Thailand and Indonesia. This proves that the Vietnam start-up movement has extraordinary vitality and potential development. Clearly, Vietnam is witnessing the rise of a strong generation of young businessmen. They are confident, drastic and dare to create jobs for themselves and for many others

However, the impression that these companies left is not remarkable. According to VCCI (2015), young businesses are likely to collapse in the first years of running a business: it is estimated that in the last 2 years, $80 \%$ of 100 startups face the risk of dissolution in the first working year. The main reasons are the lack of capital (occupied 40\%), the lack of knowledge about the management skill for small and medium enterprises (accounting for $50 \%$ ), the lack of practical experience in the business environment (accounting for 30\%). In other words, there is a high proportion of young students and entrepreneurs looking for luck in starting a business.

Along with the rocketing importance of entrepreneurship in business practice. An increase in the level of interest in entrepreneurship is also found in academia, and many researches in this field have also been conducted to investigate startup and related aspects such as intention and entrepreneurial behavior (Bird, 1988, Kolvereid, 1996, Tkachev and Kolvereid, 1999, Mazzarol and Soutar, 1999, Misra and Kumar, 2000), they proposed the different behavioral directions and entrepreneurial intentions. For example, Mazzarol and Soutar (1999), based on previous studies, proposed two premise factors to start a business, which are the environment and the personality.

The main objective of this study is to examine the personal and environmental factors that influence entrepreneurial intention. In addition, the study also consider whether there is a difference between male and female students, between the technical students and the economics students, between the students who have worked and students who have not worked in assessing the impact of factors on student's intention to start a business in Hanoi.

\section{Theoretical framework and research hypothesis}

Studies about the factors affecting entrepreneurial intention were appeared 50 years ago and were dominated by a wide range of social sciences other than economics (Indarti and Krinstiansen, 2003). For instance, the need for achievements is the desire for excellent results, achievement, controlling by setting high standards and striving to accomplish them. It is a consistent concern with ameliorate things (McClelland et al., 1976). Moreover, Crant (1996) proposed the theory of initative as a predictor of entrepreneurial intention, which is a valuable supplement for the predictive personality variables of entrepreneurial intention. Self-efficacy is also used in the study of factors that influence student entrepreneurial intentions. Self-efficacy is people's belief, consideration to create designated levels of performance that affect events and life. Belief in self-efficacy determines people's feeling, thinking, motivation and behavior. Such beliefs create diverse effects through four main processes. These include of cognitive, motivational, emotional and choice processes (Zimmerman, 2000).

Several studies have focused on appreciating demographic factors as well as personal background and analyzing factors of resources and contexts that affect the intention to set up a business. Nevertheless, studies of 
entrepreneurial intention are still influenced by the psychological, sociological, and specific personality characteristics of each entrepreneur. Therefore, in the following, the theoretical discriminations between individual factors, contextual elements and demographic characteristics will be analyzed briefly:

\subsection{Personality traits}

Need for achievement: As mentioned, McClelland et al. (1976) emphasized that individual factors such as the need for achievements affects individuals in forming entrepreneurial intentions. The author described that persons with high achievement needs will often get a great desire for success. People with great score in achievements need tend to appreciate personal responsibility, fond of risks and are extremely excited about the results of their decisions. In addition, individuals with high achievement needs are more confident in themselves than usual, enjoy betting on carefully calculated risks, actively investigates the surrounding factors which affect the results and are particularly rigorous in assessing how well they are doing (McClelland, 1965). Terpstra et al. (1993) announced that the concept of the need of achievement consists of characteristics such as a person's desire to succeed, the tendency to take moderate or perceived risk tolerance, and a desire to receive condensed feedback immediately. Besides, Lee (1996) argued that the need for achievement is conceptualized as "a unified character that motivates a person to face challenges in the desire to achieve success and excellence". Scapinello (1989), in an investigation of discriminations in expression between high motivational and low motivational groups, concluded that those who have high achievement needs will find it hard to accept failure. The idea is that the need for achievement affects the expression for success or failure. Nathawat et al. (1997) discovered the low need for achievement is closely related to low capacity, low ambition, failure and tendency to self-blame, diminishing inspiration. Hence, the following hypothesis is stated:

H1: The need for achievement has a positive impact on students' entrepreneurial intentions.

Locus of control: Locus of control is another personality trait that expresses a sense of control. According to Hisrich ( 1998), locus of control should be interpreted as "an attribute expressing a sense of control which an individual has in life". When considering forming a business, people will ask themselves whether they can preserve necessary ambition and energy to address challenges related to success, management and businesses progress. Locus of control emphasizes the levels of individuals, who are aware of success or failure when it becomes extremely unpredictable compared to initial thinking (Green et al., 1996). The belief that everything happened due to fate or accident is an expression of the limitation of control, which comes from the internal factors of each individual and is equivalent to an extremely low score on locus of control scale. The level of self-control is estimated as one of the determinants affecting the characteristics of entrepreneurs (Venkatapathy, 1984). Individuals with high levels of control are often more likely to have a clearer vision of the future and develop a long-term business plan (Entrialgo et al., 2000). On the other hand, locus of control is one of the mechanisms which regulates cognitive process. Locus of control are compared with self-defense mechanisms, operates in all situations, solves all cognitive problems. Besides, according to $\mathrm{Vu}$ (2008), locus of control enables individuals to control unnecessary expressions and reactions, even if these are harmful in some specific cases. From all the arguments and analysis above, it can be said that the higher the individuals who have locus of control, the greater the intention to start a business. Thus, the hypothesis is designed as:

H2: Locus of control has a positive impact on students' entrepreneurial intentions.

Sell-efficacy: Self-efficacy was drawn from a social research hypothesis by Bandura and Walters (1977). It emphasizes an individual's belief in ability to perform when assigned to a task. From Ryan (1970) view, selfawareness has a pivotal role in shaping entrepreneurial intentions. Similarly, Cromie (2000) argued that selfefficacy affects an individual's beliefs about whether or not a clear goal is to be achieved. Moreover, self- efficacy provides a basis for individual's motivation, and the process of self-improvement; unless they believe that their actions can produce a desired result, they will have less incentive to act or maintain faith in the face of adversity (Pajares, 2002). Bandura and Walters (1977) stated the fact that "the level of motivation, efficiency, and actions are often based on people's belief rather than objective truths". An individual's perception of self-efficacy has a tremendous influence on how an individual will act and how knowledge, skills will be formed. As a result, people behave and act relied on self-efficacy rather than on objective truths about perception and competence. Cromie (2000) emphasized the need to clearly distinguish the concept of locus of control and self-efficacy. Firstly, there is a generalized structure that encompasses a variety of circumstances, while self-efficacy is a certain task and situation. Therefore, each individual may exhibit a strong sense of control in general situations or may exhibit a low self-efficacy in certain cases. Thus, we can conclude that the three internal factors that can impact on entrepreneurial intention are: self-efficacy, locus of control and the need for achievement. In consequence, we stated the following hypothesis as below:

H3: Self-efficacy has a positive impact on students' entrepreneurial intentions.

\subsection{Contextual factors - Instrumental readiness}

Contextual factors influence entrepreneurial intention, which include cultural characteristics, social relations, 
political, economic conditions, and infrastructure with institutions (Kristiansen, 2001, 2002b). In influencing the intentions and behaviors of entrepreneurs, it is not only affected by the nature and context but also significantly depended on the environment of the business. Anderson (2000) studied some startups on the outskirts of the Scotland highlands and discovered that they were either ignorant discrete of the entrepreneurship. The goal of the environment was not realistic, but now it has become a real problem for businesses. In addition, the instrumental readiness are environmental effect can sometimes be used to denote all external factors affecting a business (Gartner, 1985). There are three contextual factors that are often significantly considered by potential business entrepreneurs: capital access, information access and social networks.

- Capital access: Capital access is clearly one of the most obstacles for new startups, especially in a developing economy with the shortage of venture capital funds. Funds may come from personal savings, family support, credit systems, community savings funds or financial institutions and banks.

- Information access: According to Anand Singh and Krishna (1994), in the investigations of entrepreneurship in India has shown that the acumen in information search is one of the business characteristics. It shows the frequency of an individual's contact with various sources of information. The outcome of this activity often depends on the firm's ability to information access, through personal capacity, personal savings or community savings funds along with the social networks. In a study of agricultural businesses in Java , Kristiansen (2002a) found that access to new information is really important to the existence and progress of businesses. The availability of a new information is identified by personal characteristics, such as education level and quality of infrastructure, communication coverage and telecommunication systems.

- Social networks: Social networks are seem to be a transportation for entrepreneurs to reduce risks and transaction costs while ameliorating ideas access, knowledge and business capital (Zimmer, 1986). Entrepreneurship research has increasingly reflected the general spirit that entrepreneurs and new companies must engage in networking to survive (Huggins, 2000). Social networks include a series of formal and informal relationships between the central character and other characters in a group of acquaintances and channel representatives; thus, entrepreneurs are entitled to access to necessary resources to start a business, grow and succeed (Kristiansen and Ryen, 2002). The last one, about the contextual factors which significantly impact on entrepreneurial intention, we suggest that an individual's perceptions of the company's ability to capital and information access or the quality of social networks are seem to be a measurable factor which impacts on entrepreneurial intention. As a result, the following hypothesis is stated:

H4: The instrumental readiness has a positive impact on students' entrepreneurial intentions.

\subsection{Demography and individual background}

A numerous of previous studies have argued that personal factors such as gender, major and work experience influence on students' entrepreneurial intentions. According to research by Haus et al. (2013), the intention of start a business of average man is higher than the figure for women. Nonetheless, the gap of gender in entrepreneurship and motivational structures is too small and cannot explain completely the significant differences when forming a business.

On the other hand, the study of Trang (2018) concentrated on evaluating the factors affecting the entrepreneurial intention of engineering students in Vietnam, comparing the impact of factors on the entrepreneurial intention of different technological student groups. Similarly, Hiệp et al. (2019) investigation mainly analyzed the factors affecting the entrepreneurial intention of economic students in Ho Chi Minh City. In the world, the major is also included in one of the factors affecting the entrepreneurial intention of students belong to economic and technical major, the difference in the entrepreneurial intention of the economic and technical students is estimated in the study of Maresch et al. (2016).

Research by Indarti and Krinstiansen (2003) shows that work experience is also a factor affecting Norwegian students' entrepreneurial intentions. Although work experience is an essential factor, the research results show that there is no significant difference between business administration students who have working experience or not in Norway. According to the above analysis, we proposed the following hypothesis:

H5: Factors influencing students' entrepreneurial intentions between gender (male and female), majors (technical and economic) and work experience (worked and not yet worked) difference is different.

Based on the general analysis, the theoretical and practical contributions about the factors impact on students' entrepreneurial intentions above, we suggested a model of factors influence on students' entrepreneur intentions (Figure 1). 


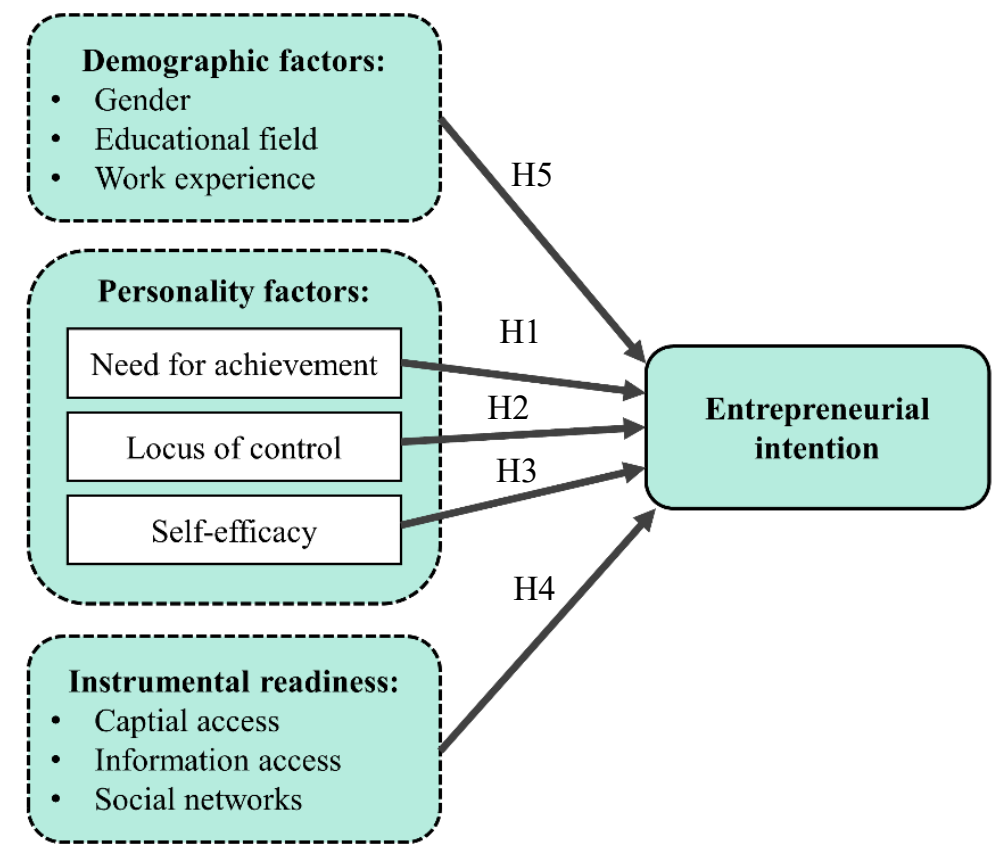

Figure 1. Research Model

\section{Research methodology}

We combined qualitative research and quantitative research in the implementation steps to evaluate the impact of factors affecting student entrepreneurial intentions according to the defined research model.

The qualitative research was used to help the research team explore the factors that influence students' entrepreneurial intentions and to adjust each factor to suit the startup situation in Vietnam.

Quantitative research is processed using a questionnaire based on the established research model through the method of surveying students' opinions. The collected data is the basis for assessing the quality of the scale, testing models and research hypotheses. Data analysis techniques such as Cronbach 'Alpha, Exploratory Factor Analysis (EFA) with the support of SPSS software version 22.0, to evaluate the quality of the scale. Meanwhile, to test the model and research hypotheses, the research team used Chartered Financial Analysis (CFA) and Structural Equation Modeling (SEM). The research model with dependent variables is start-up intention and independent variables are the influencing factors that will accurately indicate the impact of these factors on the start-up intention of Vietnamese surveyed students.

\subsection{Scale}

The scale used includes the observed variables (questions) divided into groups related to the factors that are expected to influence the entrepreneurial intentions of Vietnamese students as shown in the model in Figure 1. In particular, The author decided to use the concept and scale of Leong (2008) with 9 observed variables to measure Entrepreneurial Intention. In the same way as many authors have studied, the Need for achievement scale was evaluated with five observed variables of Leong (2008). ). Similarly, Locus of control is measured by three observed variables of Indarti and Krinstiansen (2003). Self-Efficacy is measured with 4 observed variables developed by Cassar and Friedman (2009). Finally, the Instrument Readiness scale is measured by six observed variables of Leong (2008).

\subsection{Sampling}

The study consists of two steps: preliminary research and official research. In particular, preliminary research includes qualitative research and quantitative research, the second step is conducting official quantitative research. Specifically, in qualitative preliminary research, the author conducted in-depth expert interviews and focused group interviews to complete draft scale 1 and create a draft scale 2 . Next, qualitative preliminary research were conducted with 100 elements and the results obtained 168 elements $(\mathrm{N}=80)$, in order to verify the reliability of the scales by Cronbach's Alpha and EFA reliability factors and eliminate observable variables that do not meet the standard target.

After that, the complete research questionnaire was put into official quantitative research at several universities in Hanoi city from January 2020 to February 2020. The overall study is the entire student of two disciplines of Business Administration Economics and Technical Faculty are studying at schools in Hanoi. The 
sampling method is a convenient sampling method through the online questionnaire submission.

The research questionnaire consists of 27 observed variables used in factor analysis on the principle that at least every 5 elements for 1 observed variable (Bentler and Chou, 1987). Therefore, the calculated sample number is $27 * 5=135$ elements. However, in this study, the authors intended to collect samples with a scale of 300 elements $(\mathrm{N}=300)$ to increase the reliability of the study and the result was 244 elements (questionnaire). After screening and removing invalid votes, the author used 204 valid votes for official analysis.

\section{Results and discussion}

\subsection{Exploratory Factor Analysis}

In order to run Confirmatory Factor Analysis (CFA) to check confidence and validity of the scale, the team had run factor analysis by EFA and Cronbach's Alpha.

The result of EFA and Cronbach's Alpha in Table 2 illustrates that Composite Reliability (CR) from the scale is all greater than 0.6 , Cumulative of Variance also is greater than $50 \%$, and both of 2 statistics meet the requirements. This result is generated from running Reliability Analysis to measure Cronbach's Alpha, and Factor Analysis to measure Average Variance Extracted.

Moreover, the result from EFA also show that 5 factors with 3 correlative groups have all observed variables loading toward to a single independent factor at the valid value greater than 0.5 . Thus, all factors in the scale have Convergent Validity. On top of that, EFA analysis also show that each observed variable has its loading factor responding to only one factor, so all factors have Convergent Validity. Lastly, all Corrected Item-Total Correlation values are greater than 0.3 , so the quality of the scale meets the requirement. To sum up, from the first-step analysis, variables in the research model are valid and usable for the next stage.

Table 2: Total Reliability and Cumulative of Variance of the scale

\begin{tabular}{|c|c|c|c|c|c|}
\hline No. & Scale & $\begin{array}{l}\text { No. of observed } \\
\text { variables }\end{array}$ & $\begin{array}{c}\text { Reliability of } \\
\text { Cronbach's Alpha }\end{array}$ & $\begin{array}{c}\text { Total } \\
\text { Variance } \\
\text { explained }\end{array}$ & Conclusion \\
\hline 1 & Need for Achievement & 5 & 0,899 & $71,344 \%$ & \multirow{5}{*}{$\begin{array}{l}\text { All scales } \\
\text { achieved } \\
\text { reliability }\end{array}$} \\
\hline 2 & Locus of Control & 3 & 0,820 & $73,665 \%$ & \\
\hline 3 & Self-Efficacy & 4 & 0,792 & $62,088 \%$ & \\
\hline 4 & Instrumental Readiness & 6 & 0,880 & $62,990 \%$ & \\
\hline 5 & Entrepreneurial Intention & 8 & 0,911 & $62,386 \%$ & \\
\hline
\end{tabular}

\subsection{Confirmatory Factor Analysis}

Output from CFA: Chi-square $/ \mathrm{df}=2,573 ; \mathrm{GFI}=0,911 ; \mathrm{TLI}=0.904 ; \mathrm{CFI}=0.909 ; \mathrm{RMSEA}=0.080$, prove that theoretical scale fits the real market's data.

To assess the quality and confidence of the scale in overall, we run Composite Reliability (C.R) and Average Variance Extracted (AVE) computations.

C.R and A.V.E are computed from the values based on Standardized Regression Weight statistics. The output form C.R and A.V.E computation are shown in the Table 3.

Table 3: Total C.R; A.V.E of the scale from the model

\begin{tabular}{|c|l|c|c|c|c|}
\hline No. & \multicolumn{1}{|c|}{ Scale } & $\begin{array}{c}\text { No. of observed } \\
\text { variables }\end{array}$ & C.R & $\begin{array}{c}\text { A. V. } \\
\text { E }\end{array}$ & Conclusions \\
\hline 1 & Need for Achievement & 5 & 0.823 & 0.519 & \\
\hline 2 & Locus of Control & 3 & 0.823 & 0.609 & \multirow{2}{*}{$\begin{array}{c}\text { All scales achieved } \\
\text { reliability }\end{array}$} \\
\hline 3 & Self-Efficacy & 4 & 0.836 & 0.516 & \\
\hline 4 & Instrumental Readiness & 6 & 0.852 & 0.579 & \\
\hline 5 & $\begin{array}{l}\text { Entrepreneurial } \\
\text { Intention }\end{array}$ & 8 & 0.877 & 0.500 & \\
\hline
\end{tabular}

\subsection{Testing models}

After completing the assessment of the scale, we start to test the theoretical model.

Output from model testing is presented in Pic. 2: Chi-square/df $=681.861$; GFI = 0,909; TLI =0,903; CFI =0,907; RMSEA $=0,080$, prove that the model highly matches the real market's data.

Besides, calculated results illustrate that all relationships have statistical significance $(\mathrm{P}<5 \%)$; only relationship between factor "Locus of Control" and "Entrepreneurial Intention" does not have statistical significance (P $>5 \%)$. 


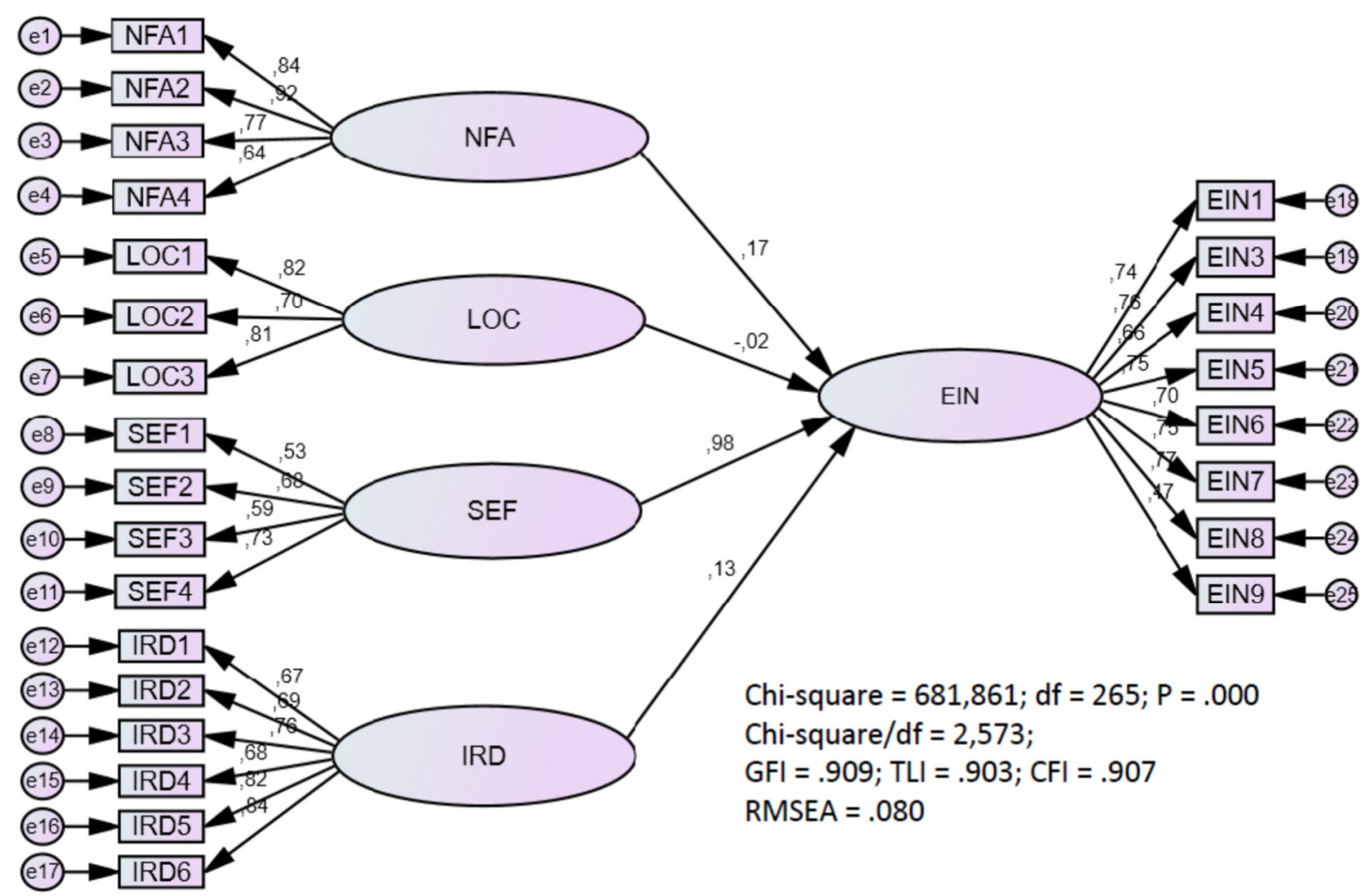

Figure 2: Structural Equation Modeling output (standardized)

Table 4: Results of Testing relationship (standardized regression Coefficients)

\begin{tabular}{|c|c|c|c|c|c|c|c|}
\hline & & & Estimate & S.E. & C.R. & P & Hypothesis \\
\hline EIN & $\leftarrow$ & NFA & .206 & .058 & 3.531 & $* * *$ & H1: Significance \\
\hline EIN & $\leftarrow$ & LOC & -.015 & .039 & -.393 & .694 & H2: Not Significance \\
\hline EIN & $\leftarrow$ & SEF & .913 & .089 & 10.309 & $* * *$ & H3: Significance \\
\hline EIN & $\leftarrow$ & IRD & .108 & .039 & 2.771 & .006 & H4: Significance \\
\hline
\end{tabular}

\subsection{Hypothesis Testing}

Hypothesis 1: By requirement $\mathrm{p}<0.05$, prove that weighted means have statistical significance. In fact, through the output, $\mathrm{p}<0.001$ and positive, Need for Achievement factor $(\mathrm{H} 1=0.206)$ affects proportionally on Entrepreneurial Intention. Thus, conclude that Needs for Achievement affect positively on Entrepreneurial Intention.

Hypothesis 2: By requirement $\mathrm{p}>0.05$, prove that weighted means don't have statistical significance. Therefore, there is no basis to assert that Locus of control affects Entrepreneurial Intention.

Hypothesis 3: By requirement $\mathrm{p}<0.05$, prove that weighted means have statistical significance. In fact, through the output, $\mathrm{p}<0.001$ and positive, Self-efficacy factor $(\mathrm{H} 3=0.913)$ affects proportionally on Entrepreneurial Intention. Thus, conclude that Self-efficacy affect positively on Entrepreneurial Intention.

Hypothesis 4: By requirement $\mathrm{p}<0.05$, prove that weighted means have statistical significance. In fact, through the output, $\mathrm{p}<0.001$ and positive, Instrumental Readiness factor $(\mathrm{H} 4=0.108)$ affects proportionally on Entrepreneurial Intention. Thus, conclude that Instrumental Readiness affect positively on Entrepreneurial Intention.

Hypothesis 5: In this study, the author analyzes Structural Equation Modeling (SEM) by attribute: personal characteristics of students intending to start a business by gender, specialty and work experience. The results confirmed the factors that influence students' entrepreneurial intentions between gender groups (male and female), majors (engineering and economics) and work experience (worked and not yet worked) are different.

\section{Conclusions and recommendations}

This study has demonstrated the factors: Need for Achievements, Self- efficacy, and Instrumental Readiness that affect the entrepreneurial intention of students. Although these factors are very complex, both the overall analysis and the actual research have the results that these factors have a positive effect on students' entrepreneurial intentions in Hanoi. In particular, the factor Confidence in self-efficacy is the most powerful factor $(\mathrm{H} 3=0.913)$, while the factor Instrumental readiness is the lowest impactful factor $(\mathrm{H} 4=0.1108)$. 
In addition, the study also clarify that there is a difference between male and female students; between students of economic majors and students of technical majors and between students who have worked and students who have not worked in assessing the impact of factors on student's intention to start a business in Hanoi.

The results of the study have suggested a number of implications to motivate students' entrepreneurial intentions.

First, universities, even the Vietnamese government, should research, select and apply training programs that emphasize entrepreneurship, which can be a good way to increase the level of intention of students to start up. The training program should also focus on the knowledge and skills to enhance students' entrepreneurial intentions or integrate more specialized entrepreneur courses in current curriculum. In order to equip the necessary skills, besides, specialized skills. In addition, the Universities should also have activities such as organizing Entrepreneur days, meeting students with young businesses so that students can be motivated to "dare to think and dare to do it"

Second, universities should provide activities which can promote entrepreneurship into the program is also one of the essential goals. The universities should organize entrepreneurship competitions, start-up ideas, or networking meetings among young people who share the same ambition. The propaganda also plays a very important role in promoting intentions to start a business. In addition, each university or college should set up entrepreneur centers to create an environment for Vietnamese students to approach and implement start-up projects.

Third, universities, governments and organizations that focus on these activities, also need to consider carefully the strategies, mechanisms, and programs to enable each entrepreneur to have access to fund, information and social network. These are important factors that influence students' entrepreneurial intentions. The capital may come from personal savings, family support, credit systems and community savings funds or financial institutions and banks. In addition, it is necessary to have an information base system to support students to find and access new and precise information about entrepreneurial activities, especially information about entrepreneurship spirit because so far, a part of students do not fully understand about entrepreneurship and entrepreneurship or discrete it. Moreover, it is also necessary to create a social network of relationships and consider it an important means for entrepreneurs to reduce risk and transaction costs, at the same time, improve the ability of access to ideas, knowledge and business capital.

Fourth, from students' case, any decision to start a business should be made with caution. Whether you truly dare to face the responsibilities, risks, challenges of a leader or simply, you want to be a normal employee in a famous company. The results of this study reinforce the argument that the bravery and intention to start a business will greatly determine the student's perceptions and success rate of the project.

Fifth, students should actively participate in some activities such as start-up workshops, education and training. Thereby, it can promote the entrepreneurial spirit of students and make them not only well-prepared to become good employees but also qualified entrepreneurs.

In short, based on the results of surveys, this research provides some new, more specific findings on the determinants affecting students' entrepreneurial intention. These findings can help universities, governments and organizations find solutions to promote the entrepreneurial intention of Vietnam's students, developing entrepreneurial movement in Vietnam.

\section{References}

Anand Singh, K. and Krishna, K. (1994). 'Agricultural entrepreneurship: the concept and evidence', The Journal of Entrepreneurship, 3(1), pp. 97-111.

Anderson, A. R. (2000). 'Paradox in the periphery: an entrepreneurial reconstruction?', Entrepreneurship \& Regional Development, 12(2), pp. 91-109.

Bandura, A. and Walters, R. H. (1977) Social learning theory. Prentice-hall Englewood Cliffs, NJ.

Bentler, P. M. and Chou, C.P. (1987). 'Practical issues in structural modeling', Sociological Methods \& Research, 16(1), pp. 78-117.

Bird, B. (1988). 'Implementing entrepreneurial ideas: The case for intention', Academy of management Review, 13(3), pp. 442-453.

Cassar, G. and Friedman, H. (2009). 'Does self-efficacy affect entrepreneurial investment?', Strategic Entrepreneurship Journal, 3(3), pp. 241-260.

Crant, J. M. (1996). 'The proactive personality scale as a predictor of entrepreneurial intentions', Journal of small business management, 34, pp. 42-49.

Cromie, S. (2000). 'Assessing entrepreneurial inclinations: Some approaches and empirical evidence', European journal of work and organizational psychology, 9(1), pp. 7-30.

Entrialgo, M., Fernández, E. and Vázquez, C. J. (2000). 'Characteristics of managers as determinants of entrepreneurial orientation: some Spanish evidence', Enterprise and innovation management studies, 1(2), pp. 187-205.

Gartner, W. B. (1985). 'A conceptual framework for describing the phenomenon of new venture creation', Academy of management review, 10(4), pp. 696-706. 
Green, R., David, J., Dent, M. and Tyshkovsky, A. (1996). 'The Russian entrepreneur: a study of psychological characteristics', International journal of entrepreneurial behavior \& research.

Haus, I., Steinmetz, H., Isidor, R. and Kabst, R. (2013). 'Gender effects on entrepreneurial intention: A metaanalytical structural equation model', International Journal of Gender and Entrepreneurship, 5(2), pp. 130156.

Hiep, N. X., Thanh, T. H. and Nhi, N. T. Y. (2019). 'Các yếu tố ảnh hưởng đến ý định khởi nghiệp kinh doanh của sinh viên khối ngành kinh tế các trường đại học tại thành phố Hồ Chí Minh'.

Hisrich, R. D., and M. P. Peters. ( 1998). ' Entrepreneurship'. 4th Edition, McGraw Hill, Boston,

Huggins, R. (2000). 'The success and failure of policy-implanted inter-firm network initiatives: motivations, processes and structure', Entrepreneurship \& Regional Development, 12(2), pp. 111-135.

Indarti, N. and Krinstiansen, S. (2003). 'Determinants of entrepreneurial intention: The case of Norwegian students', Gadjah Mada International Journal of Business, 5(1), pp. 79-95.

Kolvereid, L. (1996). 'Prediction of employment status choice intentions', Entrepreneurship Theory and practice, 21(1), pp. 47-58.

Kristiansen, S. (2001). 'Promoting African pioneers in business: what makes a context conducive to small-scale entrepreneurship?', The Journal of Entrepreneurship, 10(1), pp. 43-69.

Kristiansen, S. (2002a). 'Competition and knowledge in Javanese rural business', Singapore Journal of Tropical Geography, 23(1), pp. 52-69.

Kristiansen, S. (2002b). 'Individual perception of business contexts: The case of small-scale entrepreneurs in Tanzania', Journal of Developmental Entrepreneurship, 7(3), pp. 283.

Kristiansen, S. and Ryen, A. (2002). 'Enacting their business environments: Asian entrepreneurs in East Africa', African and Asian Studies, 1(3), pp. 165-186.

Lee, J. (1996) 'The motivation of women entrepreneurs in Singapore', Women in Management Review.

Leong, C. K. (2008). Entrepreneurial intention: an empirical study among Open University Malaysia (OUM) students. Open University Malaysia (OUM).

Maresch, D., Harms, R., Kailer, N. and Wimmer-Wurm, B. (2016). 'The impact of entrepreneurship education on the entrepreneurial intention of students in science and engineering versus business studies university programs', Technological forecasting and social change, 104, pp. 172-179.

Mazzarol, T. and Soutar, G. N. (1999). 'Sustainable competitive advantage for educational institutions: a suggested model', International Journal of Educational Management.

McClelland, D. C. (1965). 'Achievement and entrepreneurship: A longitudinal study', Journal of personality and Social Psychology, 1(4), pp. 389.

McClelland, D. C., Atkinson, J. W., Clark, R. A. and Lowell, E. L. (1976). 'The achievement motive'.

Misra, S. and Kumar, E. S. (2000). 'Resourcefulness: A proximal conceptualisation of entrepreneurial behaviour', The Journal of Entrepreneurship, 9(2), pp. 135-154.

Nathawat, S., Singh, R. and Singh, B. (1997). 'The effect of need for achievement on attributional style', The Journal of social psychology, 137(1), pp. 55-62.

Pajares, F. (2002). 'Overview of Social Cognitive Theory and Self-efficacy,[Online] Available: http://www. emory. edu', EDUCATION/mfp/eff. html.

Ryan, T. A. (1970). 'Intentional behavior: An approach to human motivation'.

Scapinello, K. F. (1989). 'Enhancing differences in the achievement attributions of high-and low-motivation groups', The Journal of social psychology, 129(3), pp. 357-363.

Terpstra, D. E., Rozell, E. J. and Robinson, R. K. (1993). 'The influence of personality and demographic variables on ethical decisions related to insider trading', The Journal of Psychology, 127(4), pp. 375-389.

Tkachev, A. and Kolvereid, L. (1999). 'Self-employment intentions among Russian students', Entrepreneurship \& Regional Development, 11(3), pp. 269-280.

Trang, D T. T. (2018). 'Đánh giá những yếu tố ảnh hưởng tới ý định khởi nghiệp của sinh viên Việt Nam: Nghiên cứu trường hợp sinh viên khối ngành kỹ thuật'.

VCCI (2015). 'Báo cáo chỉ số khởi nghiệp VN GEM 2015' (Accessed.

Venkatapathy, R. (1984). 'Locus of control among entrepreneurs: A review', Psychological Studies, 29(1), pp. 97100

Vu, D. (2008). Tù điển tâm lý học. NXB Từ điển Bách khoa, Hà Nội, Việt Nam.

Zimmer, C. (1986). 'Entrepreneurship through social networks', The art and science of entrepreneurship. Ballinger, Cambridge, $M A, 3$, pp. 23.

Zimmerman, B. J. (2000). 'Self-efficacy: An essential motive to learn', Contemporary educational psychology, 25(1), pp. 82-91. 